Original scientific paper

UDC: 634.41:599.731.1

DOI: 10.15679/bjwr.v4i2.54

\title{
CONCENTRATION OF SELECTED HEAVY METALS IN BROWN HARE (Lepus europaeus) AND WILD BOAR (Sus scrofa) FROM CENTRAL TURKEY
}

\author{
Demirbaş $Y .^{1}$, Erduran $N .^{2}$
}

Summary: In the present study, concentrations of heavy metals viz. chromium (Cr), manganese $(\mathrm{Mn})$, copper $(\mathrm{Cu})$, zinc $(\mathrm{Zn})$, cadmium $(\mathrm{Cd})$, mercury $(\mathrm{Hg})$, lead $(\mathrm{Pb})$, and a metalloid selenium (Se) were examined in kidney, liver and muscle tissues of 15 brown hares (Lepus europaeus) and 9 wild boars (Sus scrofa) obtained from Kirıkkale province located in central Turkey. Significant variation in the concentrations of the studied heavy metals in the selected tissues was recorded. Mean concentrations of Cr (1.02 mg/kg), Mn (6.00 mg/kg), Se (1.15 mg/kg) and Cd (4.49 mg/kg) were the highest in hare kidney compared to other tissues, whereas concentrations of $\mathrm{Cu}(2.34$ $\mathrm{mg} / \mathrm{kg})$ and $\mathrm{Zn}(40.51 \mathrm{mg} / \mathrm{kg})$ were the highest in hare liver, and $\mathrm{Pb}(7.83 \mathrm{mg} / \mathrm{kg})$ was the highest in hare muscle. On the other hand, mean concentrations of $\mathrm{Cr}(1.82 \mathrm{mg} / \mathrm{kg}), \mathrm{Cu}(1.25 \mathrm{mg} / \mathrm{kg})$, Se (3.55 $\mathrm{mg} / \mathrm{kg}$ ) and Cd (3.05 mg/kg) were the highest in boar kidney compared to liver and muscle tissues, whereas concentrations of $\mathrm{Mn}(3.89 \mathrm{mg} / \mathrm{kg})$ and $\mathrm{Pb}(0.75 \mathrm{mg} / \mathrm{kg})$ were the highest in boar liver, and $\mathrm{Zn}(45.65 \mathrm{mg} / \mathrm{kg})$ was the highest in boar muscle. Strong positive significant correlations were found between $\mathrm{Cr}$ and $\mathrm{Hg}$, and between $\mathrm{Cu}$ and $\mathrm{Pb}$ concentrations in kidney in all wild boar samples. There were also strong positive significant correlations between $\mathrm{Cd}$ and $\mathrm{Pb}$ concentrations in liver and $\mathrm{Cd}$ and $\mathrm{Pb}$ concentrations in muscle in all hare samples. Our results revealed that $\mathrm{Hg}$ (1/9 boar kidney; 4/15 hare kidney), Cr (9/9 boar all three tissues; 9/15 hare kidney and 11/15 hare liver), $\mathrm{Pb}$ (4/9 boar muscle; 5/15 hare liver, 15/15 hare muscle) and Cd (9/9 boar all three tissues; 15/15 hare all three tissues) concentrations detected in wild boar and hare tissues in the present study were higher than the hygienic limits.

Key words: Lepus europaeus, Sus scrofa, heavy metals, environmental pollution, tissues, central Turkey

\section{Introduction}

The contaminants that have a toxic effect on organisms in ecosystems and disturb the balance among the living organisms are metals, pesticides, Polychloro Biphenyls (PCB) and Polyaromatic Hydrocarbons (PAH) (Webb et al., 2002). Heavy metals are among the most hazardous contaminants due to their extensive use. At the present time, as a result of increasing populations, urbanization, industrialization and intensive agricultural activities, increasing concentrations of heavy metals are found in all living organisms (Örün and Yalçın, 2011; Tunca et al., 2012).

\footnotetext{
${ }^{1}$ Demirbaş Yasin, PhD, assistant, University of Kırıkkale, Faculty of Science and Arts, Department of Biology, 71450 Yahsihan, Kırıkkale, Turkey;

${ }^{2}$ Erduran Nuran, PhD, assistant, University of Kırıkkale, Faculty of Science and Arts, Department of Chemistry, 71450 Yahsihan, Kirıkkale, Turkey.
} 
The leakage of heavy metals present in soil, water and air into the food chain is a significant environmental concern and leads to high risks for the living organisms in the ecosystem. It is reported that the high levels of some heavy metals could have lethal and sublethal effects on mammals (Iwegbue, 2008; Danieli et al., 2012). Game meat and offal widely consumed by humans are known to be a significant source of heavy metals. Toxic accumulation of heavy metals in soil and plants entails a high risk of transferring heavy metals to herbivorous/omnivorous wild mammals, game and farm animals. It is reported that the levels of contaminants in wild animals are higher than those in domestic animals (Chen et al., 2001; Bilandžić et al., 2010).

Mammals such as brown hare (Lepus europeaus), red fox (Vulpes vulpes), wild boar (Sus scrofa), roe deer (Capreolus capreolus), mink (Mustela vison), wood mouse (Apodemus flavicolis), fallow deer (Dama dama), red deer (Cervus elaphus), and golden jackal (Canis aureus) are useful indicators of heavy metal pollution mainly due to their relatively longer lifespan (Medvedev, 1999; Wajdzik, 2006; Kramárová et al., 2005; Srebočan et al., 2011; Filistowicz et al., 2012; Ćirović et al., 2015). A long-term chemical accumulation in such animals provides an early warning of negative toxic effects for the general compartments of the ecosystem (Bilandzić et al., 2010). These studies, based on toxicity tests and bioaccumulation experiments, are highly significant for protection of ecosystems (Tunca, 2012).

As an indicator of environmental pollution, heavy metals are required to be constantly monitored. Though environmental pollution is recognized as one of the most important causes of the decrease in natural population, only one ecotoxic study has been conducted on wild mammals from southern region of Turkey until today (Yarsan et al., 2014). Turkish brown hare (Lepus europeaus) and wild boar (Sus scrofa) are among the most popular game animals which show large geographical distribution throughout Turkey. The purpose of this study was to determine the concentrations of the selected heavy metals (Cr, Mn, Cu, Zn, Cd, Hg, and $\mathrm{Pb}$ ) and a metaloid Se in the kidney, liver, and muscle tissues of hares and wild boars from Kirıkkale province in the central region of Turkey. This monitoring is also important because the investigated animals are consumed by some people in Turkey

\section{Material and Methods}

\section{Study area}

This study was conducted on kidney, liver, and muscle tissue samples obtained from central

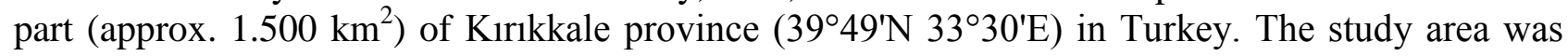
covered mainly by cropland where wheat, barley, sunflower, sugar beet, watermelon, melon, and oak clover are cultivated. Also, there was a forest vegetation formed by oak scrubs and black pine in Balışeyh region and other forest vegetation formed by Turkey oak, downy oak and laurel-leaf cistus associations in Keskin region (Dönmez, 2002; Hamzaoğlu and Duran, 2004; Hamzaoğlu, 2005). Agriculture is a dominant economic activity at study area with usage of herbicides, pesticides, and fertilizers during production. In terms of transportation, Kurıkkale province is one of the most important crossroads in Turkey. On the other hand, there are large industrial facilities such as Mechanical and Chemical Industry and the Central Anatolian Oil Refinery. The mentioned industrial facilities located in west-central part of Kirıkkkale are in studied area.

\section{Collected material}

Kidney, liver, and muscle samples of adult hares $(n=15)$ and wild boars $(n=9)$ were collected in cooperation with a local hunting organization during the hunting season of 2013/2014 (September-February). Muscle samples were collected from the upper hind legs. The age determinations were identified according to the pronouncedness of sutures in the cranial bones 
(between the frontal and sagittal bones) and the morphological structure of processus supraorbitalis (Suchentrunk et al., 2000) in hares and the external and cranial characteristics (İnci 2003) in wild boars. Ammunition parts in the tissues were noticed and samplings were done far from these spots. Upon collection, all tissue samples were placed into labeled plastic bags and stored at $-20{ }^{\circ} \mathrm{C}$ until the analysis of the pronouncedness of sutures in the cranial bones (between the frontal and sagittal bones) and the morphological structure of processus supraorbitalis (Suchentrunk et al., 2000)

\section{Determination of heavy metals}

For the analysis, the samples of approximately $1 \mathrm{~g}$ were taken from kidney, liver and muscle tissues and those samples were put into glass vials. The samples were kept in an incubator (Nüve) set to 70 ${ }^{\circ} \mathrm{C}$ for 16 hours. In order to make the dehydrated samples soluble, $3 \mathrm{~mL}$ of concentrated $\mathrm{HNO}_{3}$ (65\% v/v Merck) was applied to the liver and muscle samples and $2.5 \mathrm{~mL} \mathrm{HNO}_{3}$ was applied to the kidney samples; and the results were kept in a shaking water bath for a night. In order to carry out the oxidation process, $2 \mathrm{~mL} \mathrm{H}_{2} \mathrm{O}_{2}$ (35\% v/v Merck) was applied to each sample, and each sample was kept in the incubator set to $110^{\circ} \mathrm{C}$ for 3-4 hours until each sample turned clear. At the end of this period, the volumes of cooled liver and muscle samples were diluted to $30 \mathrm{~mL}$ by using purified water the volumes of kidney samples were diluted to $25 \mathrm{~mL}$ and the samples were put into capped polyethylene tubes.

Concentrations of heavy metals chromium $(\mathrm{Cr})$, mangan $(\mathrm{Mn})$, copper $(\mathrm{Cu})$, zinc $(\mathrm{Zn})$, cadmium $(\mathrm{Cd})$, mercury $(\mathrm{Hg})$, lead $(\mathrm{Pb})$ and a metaloid selenium (Se) in the samples were measured on a wet weight basis. “Agilent 7500 Inductively Coupled Plasma-Mass Spectrometry (ICP-MS)” device was used to determine heavy metal concentrations in the samples. The results taken from the ICPMS were multiplied with the dilution volume and the results were divided based on the mass of the samples and presented as $\mathrm{mg} \mathrm{kg}^{-1}$.

The hygienic limits of heavy metals were determined according to the Turkish Food Codex and Piskorovà et al. (2003).

\section{Statistical analyses}

As the heavy metal concentrations were not normally distributed, the nonparametric MannWhitney U-test was used for statistical comparisons between sexes and tissues of the two species, and Kruskal-Wallis test for comparisons between different tissues of the same species. Correlations between the heavy metal concentrations of the tissue samples belonging to hare and wild boar were calculated by using Pearson's correlation coefficient. Significant differences were accepted at the probability level of $\mathrm{P}<0.05$. Statistical analyses were conducted by using PASW Statistics 18 (SPSS 2010).

\section{Results and discussion}

Statistical analysis showed no significant difference between the sexes, and so the data were combined from both sexes in the subsequent analyses.

Table 1 showed mean concentrations of $\mathrm{Cr}, \mathrm{Mn}, \mathrm{Cu}, \mathrm{Zn}, \mathrm{Se}, \mathrm{Cd}, \mathrm{Pb}$, and $\mathrm{Hg}$ in the kidney, liver and muscle samples of hares and wild boars in Kirıkkale province. While significant differences were found in $\mathrm{Mn}, \mathrm{Cu}, \mathrm{Zn}$, Se, and Cd concentrations among tissues of wild boars, significant differences were found in $\mathrm{Cr}, \mathrm{Mn}, \mathrm{Cu}, \mathrm{Zn}$, Se, $\mathrm{Cd}$, and $\mathrm{Pb}$ concentrations among tissues of hares $(\mathrm{P}<0.05)$. On the other hand, there were significant differences between these animals in terms of $\mathrm{Cr}, \mathrm{Mn}, \mathrm{Cu}$, and 
Se concentrations in kidney, $\mathrm{Cr}$ and Se concentrations in liver, and $\mathrm{Cr}, \mathrm{Mn}, \mathrm{Zn}, \mathrm{Cd}$, and $\mathrm{Pb}$ concentrations in muscle $(\mathrm{P}<0.05)$ (Table 1$)$.

Table 1. Concentrations (mean $\pm \mathrm{SD})(\mathrm{mg} / \mathrm{kg})$ and the results of comparison of eight heavy metals in kidney, liver, and muscle of hares (Lepus europaeus) and wild boars (Sus scrofa) in Kirikkale, 2013-2014.

\begin{tabular}{|c|c|c|c|c|c|}
\hline $\begin{array}{l}\text { Heavy } \\
\text { metals }\end{array}$ & Species & Kidney & Liver & Muscle & $\mathrm{P}_{\mathrm{KW}}$ \\
\hline \multirow{3}{*}{$\mathrm{Cr}$} & L. europaeus & $1.02 \pm 0.90$ & $1.00 \pm 0.78$ & $0.24 \pm 0.06$ & $0.00 *$ \\
\hline & S. scrofa & $1.82 \pm 1.79$ & $1.30 \pm 0.77$ & $1.35 \pm 0.59$ & 0.90 \\
\hline & $\mathrm{P}_{\mathrm{MW}}$ & $0.03^{*}$ & $0.02 *$ & $0.00 *$ & \\
\hline \multirow{3}{*}{$\mathrm{Mn}$} & L. europaeus & $6.00 \pm 3.27$ & $4.80 \pm 1.23$ & $1.51 \pm 0.40$ & $0.00 *$ \\
\hline & S. scrofa & $3.20 \pm 0.76$ & $3.89 \pm 0.68$ & $1.00 \pm 0.18$ & $0.00 *$ \\
\hline & $\mathrm{P}_{\mathrm{MW}}$ & $0.02^{*}$ & 0.44 & $0.00 *$ & \\
\hline \multirow{3}{*}{$\mathrm{Cu}$} & L. europaeus & $1.91 \pm 2.33$ & $2.34 \pm 2.81$ & $0.63 \pm 0.14$ & $0.00^{*}$ \\
\hline & S. scrofa & $1.25 \pm 0.41$ & $0.71 \pm 0.19$ & $0.45 \pm 0.21$ & $0.00 *$ \\
\hline & $\mathrm{P}_{\mathrm{MW}}$ & $0.00 *$ & 0.08 & 0.08 & \\
\hline \multirow{3}{*}{ Zn } & L. europaeus & $32.65 \pm 6.58$ & $40.51 \pm 9.13$ & $20.35 \pm 6.93$ & $0.00 *$ \\
\hline & S. scrofa & $32.15 \pm 4.85$ & $38.85 \pm 5.54$ & $45.65 \pm 13.72$ & $0.03 *$ \\
\hline & $\mathrm{P}_{\mathrm{MW}}$ & 0.24 & 0.34 & $0.00 *$ & \\
\hline \multirow{3}{*}{ Se } & L. europaeus & $1.15 \pm 0.39$ & $0.19 \pm 0.13$ & $0.03 \pm 0.02$ & $0.00 *$ \\
\hline & S. scrofa & $3.55 \pm 0.74$ & $0.42 \pm 0.09$ & $0.08 \pm 0.03$ & $0.00 *$ \\
\hline & $P_{\mathrm{MW}}$ & $0.00 *$ & $0.00 *$ & 0.29 & \\
\hline \multirow{3}{*}{ Cd } & L. europaeus & $4.49 \pm 4.74$ & $0.83 \pm 0.46$ & $1.19 \pm 0.45$ & $0.00 *$ \\
\hline & S. scrofa & $3.05 \pm 0.99$ & $0.61 \pm 0.15$ & $0.51 \pm 0.02$ & $0.00^{*}$ \\
\hline & $\mathrm{P}_{\mathrm{MW}}$ & 0.77 & 0.11 & $0.00 *$ & \\
\hline \multirow{3}{*}{$\mathrm{Pb}$} & L. europaeus & $1.23 \pm 1.22$ & $2.19 \pm 2.87$ & $7.83 \pm 5.72$ & $0.00^{*}$ \\
\hline & S. scrofa & $0.52 \pm 0.18$ & $0.75 \pm 0.51$ & $0.44 \pm 0.17$ & 0.45 \\
\hline & $\mathrm{P}_{\mathrm{MW}}$ & 0.43 & 0.22 & $0.00 *$ & \\
\hline \multirow{3}{*}{$\mathrm{Hg}$} & L. europaeus & $0.10 \pm 0.12$ & $0.06 \pm 0.03$ & - & 0.97 \\
\hline & S. scrofa & $0.12 \pm 0.17$ & - & - & - \\
\hline & $\mathrm{P}_{\mathrm{MW}}$ & 0.37 & - & - & - \\
\hline
\end{tabular}

( $\mathrm{P}_{\mathrm{MW}}$ : Significance level of Mann-Whitney U-test, $\mathrm{P}_{\mathrm{KW}}$ : Significance level of Kruskal-Wallis test)

Correlation analysis showed significant correlations between metal concentrations accumulated in different tissues. The significant correlation was found between $\mathrm{Cu}$ concentrations in kidney and liver of wild boars $(r=-0.84, \mathrm{P}=0.011)$. A strong statistically significant correlation was found between Se concentrations in liver and muscle of wild boars $(r=-0.994, \mathrm{P}=0.045)$. The significant correlations were found between $\mathrm{Cr}$ and $\mathrm{Hg}(r=0.975, \mathrm{P}=0.0001)$, Mn and $\mathrm{Cd}(r=-$ 0.800, $\mathrm{P}=0.022)$ and $\mathrm{Cu}$ and $\mathrm{Pb}$ concentrations $(r=0.925, \mathrm{P}=0.002)$ in kidney in all wild boar samples. There were significant correlations between $\mathrm{Cr}$ and $\mathrm{Mn}(r=0.682, \mathrm{P}=0.030), \mathrm{Cr}$ and $\mathrm{Cu}$ $(r=0.688, \mathrm{P}=0.028)$, $\mathrm{Cr}$ and $\mathrm{Hg}(r=0.832, \mathrm{P}=0.003)$ and $\mathrm{Mn}$ and Hg concentrations $(r=0.750$, $\mathrm{P}=0.013)$ in kidney; $\mathrm{Cr}$ and $\mathrm{Zn}(r=0.724, \mathrm{P}=0.012)$, $\mathrm{Cu}$ and Se $(r=0.715, \mathrm{P}=0.013)$, Mn and $\mathrm{Hg}(r=-0.638, \mathrm{P}=0.035)$, and $\mathrm{Cd}$ and $\mathrm{Pb}$ concentrations $(r=0.914, \mathrm{P}=0.0001)$ in liver; $\mathrm{Cr}$ and Mn $(r=0.778, \mathrm{P}=0.023)$ and $\mathrm{Cd}$ and $\mathrm{Pb}$ concentrations $(r=0.996, \mathrm{P}=0.0001)$ in muscle in all hare samples.

$\mathrm{Hg}, \mathrm{Cr}, \mathrm{Pb}$, and $\mathrm{Cd}$ concentrations found in the tissues were compared to the hygienic limits viz; Hg- $0.1 \mathrm{mg} / \mathrm{kg}$ in kidney and liver, $0.03 \mathrm{mg} / \mathrm{kg}$ in muscle; $\mathrm{Cr}-0.5 \mathrm{mg} / \mathrm{kg}$ in all tissues; $\mathrm{Pb}-1$ $\mathrm{mg} / \mathrm{kg}$ in kidney and liver, $0.4 \mathrm{mg} / \mathrm{kg}$, in muscle; Cd- $1 \mathrm{mg} / \mathrm{kg}$ in kidney, $0.5 \mathrm{mg} / \mathrm{kg}$ in liver, 0.1 
mg/kg, in muscle. Our results revealed that Hg (1/9 boar kidney; 4/15 hare kidney), Cr (9/9 boar all three tissues; 9/15 hare kidney and 11/15 hare liver), Pb (4/9 boar muscle; 5/15 hare liver, 15/15 hare muscle) concentrations detected in wild boar and hare tissues in the present study were higher than the hygienic limits. The values of Cd concentrations exceed the hygienic limits in all tissues from both animals.

\section{Discussion}

The major path of heavy metal exposure in animals is oral consumption. Both age of the animal and the tissue type are important biological factors that affect the level of metal concentration Massanyi et al. (2003). Heavy metals target heart, kidney, liver, immune and nervous systems; however, kidney and liver are the most effected organs in mammals (Kolesarova et al., 2008). There were significant variation patterns of heavy metal concentrations among organs (kidney, liver and muscle) of both animals (hares vs. wild boars) in the present study. Mean concentrations of Cr (1.02 mg/kg), Mn (6.00 mg/kg), Se $(1.15 \mathrm{mg} / \mathrm{kg})$ and Cd $(4.49 \mathrm{mg} / \mathrm{kg})$ were the highest in hare kidney as compared to other organs, whereas concentrations of $\mathrm{Cu}(2.34 \mathrm{mg} / \mathrm{kg})$ and $\mathrm{Zn}(40.51 \mathrm{mg} / \mathrm{kg})$ were the highest in hare liver and $\mathrm{Pb}(7.83 \mathrm{mg} / \mathrm{kg})$ was the highest in hare muscle. It is worth noting that many authors stated that Cd was considerably accumulated in kidney and liver compared to other body organs (Toman and Massányi, 1996; Toman and Massányi, 2002; Toman et al., 2005; Shahid et al. 2013). In the present study, higher Cd concentration was recorded in kidney than in liver and muscles of Lepus europaeus, but slightly higher concentration of Cd was recorded in muscle $(1.19 \mathrm{mg} / \mathrm{kg})$ than in liver $(0.83 \mathrm{mg} / \mathrm{kg})$ of L. europaeus. This might probably be affected by random individual variations, age structure of the collected animals or a small sample size. On the other hand, mean concentrations of $\mathrm{Cr}(1.82 \mathrm{mg} / \mathrm{kg}), \mathrm{Cu}(1.25 \mathrm{mg} / \mathrm{kg}), \mathrm{Se}(3.55 \mathrm{mg} / \mathrm{kg})$ and Cd (3.05 mg/kg) were the highest in boar kidney as compared to liver and muscle tissues, whereas concentrations of $\mathrm{Mn}(3.89 \mathrm{mg} / \mathrm{kg})$ and $\mathrm{Pb}(0.75 \mathrm{mg} / \mathrm{kg})$ were the highest in boar liver, and $\mathrm{Zn}(45.65 \mathrm{mg} / \mathrm{kg})$ was the highest in boar muscle. Moreover, strong positive significant correlations were found between $\mathrm{Cr}$ and $\mathrm{Hg}$, and between $\mathrm{Cu}$ and $\mathrm{Pb}$ concentrations in kidney in all wild boar samples. There were also strong positive significant correlations between $\mathrm{Cd}$ and $\mathrm{Pb}$ concentrations in liver, and $\mathrm{Cd}$ and $\mathrm{Pb}$ concentrations in muscle in all hare samples.

Researchers have conducted many studies about the potential negative effects and accumulation of heavy metals in hares (Lepus europaeus) and wild boars (Sus scrofa) in various countries (Kramàrovà et al., 2005; Wajdzik, 2006; Bilandžić et al., 2010; Filistowicz et al., 2012; Danieli et al., 2012; Amici et al. 2012; Petrović et al., 2013). It is recorded that meat and offal of game species, such as hare and wild boar, are not suitable for human consumption because of high Cd and $\mathrm{Pb}$ concentrations in their bodies (Bilandzić et al., 2010; Shahid et al., 2013). Our results revealed that $\mathrm{Pb}_{\text {liv. }}, \mathrm{Zn}_{\text {kidn., }}$ and $\mathrm{Zn}_{\text {liv. }}$ concentrations in hares, and $\mathrm{Cd}_{\text {kidn. }}, \mathrm{Pb}_{\text {kidn. }}, \mathrm{Pb}_{\text {liv. }}, \mathrm{Cr}_{\text {kidn., }}$ and $\mathrm{Cr}_{\text {liv. }}$ concentrations in wild boars were higher than those reported in previous studies conducted on two animals in other European countries (Table 2, 3).

Pilarczyk et al. (2010) reported that the adult wild boars (age $>2$ years) from north western Poland had Se deficiency. Se concentrations detected in liver and kidney tissues of wild boars in the present study were higher than those determined by Pilarczyk et al. (2010). However, it is difficult to draw conclusions from these findings because there are restricted reference values of Se concentration in liver and kidney tissues of wild boars in other European countries.

Yarsan et al. (2014) stated that lead $(\mathrm{Pb})$ concentrations detected in hair tissues of wild boars in southern Turkey were higher than those detected in liver, kidney, and muscle tissues of wild boars in other European countries. This finding is consistent with the results obtained from both hare and 
wild boar samples in the present study. Also, the value of high lead concentration in hare musle was remarkable in the present study. It may sometimes depend on ammunition parts in tissue

Table 2. Concentrations (mg kg-1 w.w.) of $\mathrm{Cd}, \mathrm{Pb}, \mathrm{Cu}$, and $\mathrm{Zn}$ in brown hares (Lepus europaeus) from various European countries

\begin{tabular}{|c|c|c|c|c|c|c|}
\hline Country/Year & Tissue & $\mathrm{Cd}$ & $\mathrm{Pb}$ & $\mathrm{Cu}$ & $\mathrm{Zn}$ & References \\
\hline \multirow{2}{*}{$\begin{array}{l}\text { Poland/ } \\
\text { 1993-2001 }\end{array}$} & kidney & 26.10 & 1.50 & - & - & \multirow[t]{2}{*}{ Wajdzik (2006) } \\
\hline & liver & 2.27 & 1.67 & - & - & \\
\hline \multirow{2}{*}{$\begin{array}{l}\text { Serbia/ } \\
2010-2011\end{array}$} & kidney & 2.80 & - & - & 22.2 & \multirow[t]{2}{*}{ Petrović et al. (2013) } \\
\hline & liver & 0.26 & - & - & 24.9 & \\
\hline \multirow{2}{*}{$\begin{array}{l}\text { Slovakya/ } \\
2005\end{array}$} & kidney & 1.57 & - & - & - & \multirow[t]{2}{*}{ Kramàrovà et al. (2005) } \\
\hline & liver & 0.16 & - & - & - & \\
\hline \multirow{2}{*}{$\begin{array}{l}\text { Finland/ } \\
1992-1993\end{array}$} & kidney & 1.91 & $<0.50$ & 4.49 & 28.8 & \multirow[t]{2}{*}{ Venäläinen (2007) } \\
\hline & liver & 0.62 & $<0.50$ & 4.64 & 28.9 & \\
\hline \multirow{2}{*}{$\begin{array}{l}\text { Turkey/ } \\
2013-2014\end{array}$} & kidney & 4.49 & 1.23 & 1.91 & 32.65 & \multirow[t]{2}{*}{ This study } \\
\hline & liver & 0.83 & 2.19 & 2.34 & 40.51 & \\
\hline
\end{tabular}

Table 3. Concentrations (mg kg-1 w.w.) of $\mathrm{Cd}, \mathrm{Pb}, \mathrm{Cr}$, and $\mathrm{Hg}$ in wild boar (Sus scrofa) from various European countries

\begin{tabular}{|c|c|c|c|c|c|c|}
\hline Country/Year & Tissue & $\mathrm{Cd}$ & $\mathrm{Pb}$ & $\mathrm{Cr}$ & $\mathrm{Hg}$ & References \\
\hline \multirow{2}{*}{$\begin{array}{l}\text { Slovakia/ } \\
\text { 1998-1999 }\end{array}$} & kidney & 0.56 & 0.39 & 0.19 & 0.52 & \multirow[t]{2}{*}{ Piskorova et al. (2003) } \\
\hline & liver & 0.28 & 0.24 & 0.15 & 0.24 & \\
\hline \multirow{2}{*}{$\begin{array}{l}\text { Croatia/ } \\
2008-2009\end{array}$} & kidney & 2.84 & 0.18 & - & 0.07 & \multirow[t]{2}{*}{ Bilandžić et al. (2010) } \\
\hline & liver & - & - & - & - & \\
\hline \multirow{2}{*}{$\begin{array}{l}\text { Italy/ } \\
\text { 2005-2006 }\end{array}$} & kidney & - & - & - & - & \multirow[t]{2}{*}{ Danieli et al. (2012) } \\
\hline & liver & 0.08 & 0.33 & 0.15 & - & \\
\hline \multirow{2}{*}{$\begin{array}{l}\text { Italy/ } \\
2004-2010\end{array}$} & kidney & 1.05 & 0.29 & - & - & \multirow{2}{*}{ Amici et al. (2012) } \\
\hline & liver & 0.08 & 0.31 & - & - & \\
\hline \multirow{2}{*}{$\begin{array}{l}\text { Turkey/ } \\
\text { 2013-2014 }\end{array}$} & kidney & 3.05 & 0.52 & 1.82 & 0.12 & \multirow[t]{2}{*}{ This study } \\
\hline & liver & 0.61 & 0.75 & 1.30 & - & \\
\hline
\end{tabular}

However, samplings in this study were done far from these spots. Hence, the cause of the excess lead in hare muscle should be reevaluated in more comprehensive physiological and ecotoxicological studies. Heavy metals such as $\mathrm{Cd}, \mathrm{Hg}$, and $\mathrm{Pb}$ are highly toxic and may induce impaired reproduction and teratogenicity in animals and human (Telisman et al., 2010; Gunnarsson et al., 2004; Kolesarova et al., 2008). A high intake of $\mathrm{Cr}$ depending on oxidation state can be toxic and carcinogenic (Tarley et al., 2001; Bielicka et al., 2005). $\mathrm{Hg}, \mathrm{Cr}$, and $\mathrm{Pb}$ concentrations detected in hare and wild boar tissues in the present study were higher than the hygienic limits for some individuals, whereas the values of Cd concentrations exceeded the hygienic limits in all tissues of both animals. Namely, our findings showed that meat and offal of hares and wild boars contain some metals above the hygienic limits. This might be associated with the fact that Kirikkale province has various industrial facilities and it is an important crossroads in terms of transportation. Moreover, herbicides, pesticides and fertilizers containing potentially toxic trace elements are used in agricultural production in the studied area. 


\section{Conclusion}

In conclusion, the presented results suggest that high concentrations of some heavy metals might be an environmental problem because most species of wild animals are components of the food chain of humans. Therefore, determining the concentration of such heavy metals should be undertaken as primary study topics. In addition to these studies, combined scientific studies on the level of anthropogenic pollution and chemical composition of soil, water and air in studied areas will help scientists to get more information about the current status of environmental pollution.

\section{Acknowledgment}

This study was financially supported by the Scientific Researches Projects Coordination Unit of Kirıkkale University (Project number: BAP- 2013/34). We would like to thank the Turkish Nature Protection and National Parks Directorate (Turkish Forestry and Water Works Ministry, Ankara) for giving a research permit.

\section{References}

1. Amici A., Danieli P.P., Russo Primi C., R., Ronchi B. (2012): Consentrations of Some Toxic and Trace Elements in Wild Boar (Sus scrofa) Organs and Tissues in Different Areas of the Province of Viterbo, Central Italy. Italian Journal of Animal Science, 11, pp. 354-362.

2. Bielicka A., Bojanowska I., Wiśniewski A. (2005): Two Faces of Chromium - Pollutant and Bioelement. Polish Journal of Environmental Studies, 14, pp. 5-10.

3. Bilandzić N., Sedak M., Dokic M., Simic A. (2010): Heavy Metal Concentrations in Tissues of Wild Boar of Continental Croatia. International Journal of Environmental Protection, 2, pp. 6-9.

4. Chen Z.S., Lin H.T., Hseu Z.Y. (2001): Transfer of cadmium into the food chain from aquatic and agricultural ecosystems. In: Environmental Cadmium in Food Chain: Sources, Pathways and Risks. pp: 110-115. J.K. Syers and M. Gochfel (eds.). Belgian Academy of Science, Brussels, Belgium.

5. Ć́irović D., Gizejewska A., Jovanovic V., Penezic A., Milenkovic M., Vujošević M., Blagojević J. (2015): Concentration of Selected Trace Elements in the Golden Jackal (Canis aureus L., 1758) Population from Serbia. Acta Zoologica. Bulgarica, 67, pp. 409-414.

6. Danieli P.P., Serrani F., Primi R., Ponzetta M.P., Ronchi B., Amici A. (2012). Cadmium, Lead, and Chromium in Large Game: A Local: -Scale Exposure Assessment for Hunters Consuming Meat and Liver of Wild Boar. Archives of Environmental Contamination and Toxicology, 63, pp. 612-627.

7. Dönmez A.A. (2002): Flora of Karagüney Mountain (Kırıkkale). Turkish Journal of Botany, 26, pp. 417-451.

8. Filistowicz A., Przysiecki P., Nowicki S., Filistowicz A., Durkalec M. (2012): Contents of Copper, Chromium, Nickel and Zinc in Hair and Skin of Farm FoxesPolish Journal of Environmental Studies, 21, pp. 865-869.

9. Gunnarsson D., Svensson M., Selstam G., Nordberg G. (2004). Pronounced Induction of Testicular PGF201 and Suppression of Testosterone by Cadmium-Prevention by Zinc. Toxicology, 200, pp. 49-58.

10. Hamzaoğlu E., Duran A. (2004): Dinek Dağı (Kırıkkale) Bozuk Orman Vejetasyonu Üzerinde Fitososyolojik Bir Araştırma. Gazi Üniversitesi Fen Bilimleri Dergisi, 17, pp. 1-13 (in Turkish).

11. Hamzaoğlu E. (2005): The Steppe Vegetation of Dinek Mountain (Kırıkkale). Gazi Üniversitesi Fen Bilimleri Dergisi, 18, pp. 1-15 (in Turkish).

12. Iwegbue C.M.A. (2008): Heavy metal composition of livers and kidneys of cattle from southern Nigeria. Veterinarski Arhiv, 78, pp. 401-410.

13. İnci S. (2003): Kırıkkale İlindeki Sus scrofa Türünün Biyoekolojisi (Mammalia: Atriodactyla). MSc, Kırıkkale University, Kirikkale, Turkey.

14. Kolesarova J., Slamecka J., Jurcik R., Tataruch F., Lukac N., Kovacik J., Capcarova M., Valent M., Massanyi P. (2008): Environmental levels of cadmium, lead and mercury in brown hares and their relation to blood metabolic parameters. Journal of Environmental Science and Health, 43, pp. 646-650.

15. Kramárová M., P. Massány1, A. Jančová, R. Toman, J. Slamečka, F. Tataruch, J. Kováčı, J. Gašparík, P. Nad, M. Skalıcká, B. Koréneková, R. Jurčík, J. Čuboň, P. Haščík, 2005. Concentration of Cadmium in the Liver And Kidneys of Some Wild and Farm Animals. Bulletin of the Veterinary Institute in Pulawy, 49, pp. 465-469.

16. Massanyi P., Tataruch F., Slamecka J., Toman R, Jurcik R. (2003): Accumulation of Lead, Cadmium, and Mercury in Liver and Kidney of the Brown Hare Lepus europaeus in Relation to the Season, Age, and Sex in the west Slovakian Lowland. Journal of Environmental Science and Health, 38, pp. 1299-309.

17. Medvedev N. (1999): Levels of heavy metals in Karelian wildlife, 1989-91. Environmental Monitoring and Assessment, 56, pp. 177-193. 
18. Örün E., Yalçın S.S. (2011): Lead, Mercury, Cadmium: Effects on Child Health and Using Hair Samples in Determination of Exposure. Ankara Üniversitesi Çevre Bilimleri Dergisi, 3, pp. 73-81.

19. Petrović Z., Teodorović V., Dimitrijević M., Borozan S., Beuković M., Milićvić D. (2013): Environmental Cd and Zn Concentrations in Liver and Kidney of European Hare from Different Serbian Regions: Age and Tissue Differences. Bulletin of Environmental Contamination and Toxicology, 90, pp. 203-207.

20. Pilarczyk B., Hendzel D., Pilarczyk R., Yomza-Marciniak A., Blaszcyk B., Dabrowska-Wieczorek M., Bakowska M., Adamowicz E., Bujak T. (2010): Liver and Kidney Concentrations of Selenium in Wild Boars (Sus scrofa) from Northwestern Poland. European Journal of Wildlife Research, 56, pp. 797-802.

21. Piskorovà L’., Vasilkovà Z., Krupicer I. (2003). Heavy Metal Residues in Tissues of Wild Boar (Sus scrofa) and Red Fox (Vulpes vulpes) in the Central Zemplin Region of the Slovak Republic. Czech Journal of Animal Science, 48, pp. 134-138.

22. Shahid N., Anwar S., Qadir A., Ali H., Suchentrunk F., Arshad H.M. (2013): Accumulation of Some Selected Heavy Metals in Lepus nigricollis from Pakistan. Journal of Basic and Applied Scientific Research, 3, pp. 339-346.

23. Srebočan E., Crnić A.P., Ekert-Kabalin A.M., Lazarus M., Jurasović J., Tomljanović K., Andreić D., Perović I.S., Rakovac R. (2011): Cadmium, Lead, and Mercury Concentrations in Tissues of Roe Deer (Capreolus capreolus L.) and Wild Boar (Sus scrofa L.) from Lowland Croatia. Czech Journal of Animal Science, 29, pp. 624-633.

24. Suchentrunk F., Alkon P.U., Willing R., Yom-Tov Y. (2000): Epigenetic Dental Variability of Israeli hares (Lepus sp.): Ecogenetic or Phylogenetic Causation? Journal of Zoology, 252, pp. 503-515.

25. Tarley C.R.T., Coltro W.K.T., Matsushita M., de Souza N.E. (2001): Characteristic Levels of Some Heavy Metals from Brazilian Canned Sardines (Sardinella brasiliensis). Journal of Food Composition and Analysis, 14, pp. 611-617.

26. Telisman S., Cvitkovi C.P., Jurasovi C.J., Pizent A., Gavella M., Roci C.B. (2000): Semen Quality and Reproductive Endocrine Function in Relation to Biomarkers of Lead, Cadmium, Zinc, and Copper in Men. Environmental Health Perspectives, 108, pp. 45-53.

27. Toman R., Massanyi P. (1996): Cadmium in selected organs of fallow deer (Dama dama), sheep (Ovis aries) brown hare (Lepus europaeus) and rabbit (Oryctolagus cuniculus) in Slovakiaournal of Environmental Science and Health Part A: Toxic/Hazardous Substances \& Environmental Engineering, 31, pp. 1043-1051.

28. Toman R., Massányi P. (2002): Changes in the testis and epididymis of rabbits after an intraperitonealandperoral administration of cadmium. Trace Elements and Electrolytes, 19, pp. 114-117.

29. Toman R., Massányi P., Lukáč N., Ducsay L., Golian J. (2005): Fertility and content of cadmium in pheasant Phasianuscolchicus. following cadmium intake in drinking water. Ecotoxicology and Environmental Safety, 62, pp. 112117.

30. Tunca E. (2012): The Use of Crayfish as a Bioindicator at the Heavy Metal Pollution. Kahramanmaraş Sütçü İmam Üniversitesi Doğa Bilimleri Dergisi, 15, pp. 29-37.

31. Tunca E., Atasagun S., Sayg1 Y. (2012): Pre-Investigation of Some Heavy Metal Accumulation in the Water, Sediment and Crayfish (Astacus leptodactylus) in Yenicaga Lake (Bolu-Turkey). Ekoloji. 21, pp. 68-76.

32. Turkish Food Codex (2011): http://www.resmigazete.gov.tr/eskiler/2011/12/20111229M3-8-1.pdf.

33. Venäläinen E.R. (2007): The Levels of Heavy Metals in Moose, Reindeer and Hares in Finland-Results of Twenty Years' Monitoring. PhD, Kuopia Univiversity, Kuopia, Finland.

34. Wajdzik M. (2006): Contents of Cadmium and Lead in Liver, Kidneys and blood of the European hare (Lepus europaeus) in Malopolska. Acta Scientiarum Polonorum. Silvarum Colendarum Ratio et Industria Lignaria, 5, pp. 135-146.

35. Webb D. (2002): Gagnon M. M. Biomarkers of Exposure in Fish Inhabiting the Swan-Canning Estuary Australia-a preliminary study. Journal of Aquatic Ecosystem Stress and Recovery, 9, pp. 259-269.

36. Yarsan E., Yipel M., Dikmen B., Altıntaş L., Ekici H. (2014): Concentrations of Essential and Non Essential Toxic Trace Elements in Wild Boar (Sus scrofa L., 1758) Tissues from Southern Turkey. Bulletin of Environmental Contamination and Toxicology, 92, pp. 10-14.

Received: 05.04.2017.

Accepted: 23.12.2017.

Demirbaş Y. , Erduran N.,(2017). Concentration of selected heavy metals in brown hare (Lepus europaeus) and wild boar (Sus scrofa) from central Turkey, Balkan Journal of Wildlife Research, 4(2), pp. 26-33. 